therefore suggest that itching in inflamed skin can be the result of pharmacological synergism in which locally synthesized prostaglandins, though not themeslves pruritogenic, sensitize nerve receptors to the pruritic effects of histamine and possibly other mediators. The existence of this pathway would not, of course, exclude the possibility that histamine and other mediators of inflammation may cause itching independently of the presence of prostaglandins as a direct action. The presence of both histamine and prostaglandins has been shown in different types of human cutaneous inflammation (Greaves and Søndergaard $1970 \mathrm{a}, 1970 \mathrm{~b}$ ), and prostaglandins are also potent liberators of endogenous histamine (Von Euler and Eliasson, 1967; Søndergaard and Greaves, 1971). Though low concentrations of prostaglandins $E_{1}$ and $E_{2}$ do not cause itching in skin they do produce signs of inflammation (Solomon et al., 1968; Søndergaard and Greaves, 1971). Our results therefore explain why corticosteroids which inhibit prostaglandin biosynthesis by human skin homogenates (Greaves and McDonald-Gibson, 1972) are antipruritics when applied locally to inflamed skin. Itch and pain are closely related sensations and it is of interest that prostaglandins are known to cause hyperalgesia in skin (Solomon et al., 1968; Ferreira, 1972). Ferriera (1972) also noted that simultaneous infusion of prostaglandin $\mathrm{E}_{1}$ and histamine caused itching. Our results shed new light on the physiology of itch, and they should be extended to include investigation of the effect of prostaglandins on threshold responses of other components of inflam- mation (vascular permeability, leucotaxis) to histamine and other vasoactive agents. We suggest that regulation of threshold responses may be an important general role of prostaglandins in inflammation.

We thank Miss Carol Ellerby for excellent technical help. Prostaglandin $\mathrm{E}_{1}$ was a gift of Upjohn Ltd. (Dr. J. Pyke). This work was financed by the Medical Research Council and Fisons Ltd. (Pharmaceutical Division).

\section{References}

Ängaård, E., Arturson, G., and Jonsson, C.-E. (1970). Acta Physiologica Scandinavica, 80, 46A.

Arturson, G., Hamberg, M., and Jonsson, C.-E. (1973). Acta Physiologica Scandinavica, 87, 270.

Ferriera, S. H. (1972). Nature New Biology, 240, 200.

Greaves, M. W., and Søndergaard, J. (1970 a). Fournal of Investigative Dermatology, 54, 365.

Greaves, M. W., and Søndergaard, J. (1970 b). Archives of Dermatology, $101,418$.

Greaves, M. W., Søndergaard, J., and McDonald-Gibson, Wendy (1971). British Medical fournal, $2,258$.

Keele, C. A., and Armstrong, D. (1964). Substances Producing Pain and Itch, p. 125. London, Edward Arnold.

Solomon, L. M., Juhlin, L., and Kirschenbaum, M. B. (1968). Fournal of Investigative Dermatology, 51, 280.

Søndergaard, J., and Greaves, M. W. (1971). British fournal of Dermatology, 84, 424 . Von Euler, W. S., and Eliasson, R. (1967). Prostaglandins, p. 139. London,
Academic Press.

\title{
New Jejunostomy Feed
}

\section{J. T. HINDMARSH, R. G. CLARK}

British Medical fournal, 1973, 3, 609-612

\section{Summary}

Three patients with duodenal fistulae were fed solely with an easily prepared, inexpensive jejunostomy feed for 14, 21 , and 23 days respectively. Sodium, potassium, and nitrogen balances became positive, diarrhoea did not develop, and body weight increased. The feed was lifesaving: the patients' superficial veins were thrombosed, and percaval feeding was considered undesirable.

\section{Introduction}

The intravenous and intragastric routes are the usual alternatives for feeding patients with prolonged intestinal dysfunction or alimentary fistulae who cannot be fed by mouth. However, the former requires continuous supervision and engenders a risk of thrombophlebitis-and caval catheterization to avoid that risk introduces others (Wilmore and Dudrick, 1969; Jones and McIntosh, 1973) - and the intragastric route is not suitable for patients with external fistulae of the duodenum. For these latter patients the intrajejunal route is suitable, but, probably because of the usually associated diarrhoea, has been rather neglected.

\footnotetext{
Department of Chemical Pathology, The Royal Infirmary, and Department of Surgery, Northern General Hospital, Sheffield

J. T. HINDMARSH, M.D., M.R.C.PATH., Assistant Professor of Pathology, Dalhousie University, Associate Pathologist (Clinical Chemistry), Nova Scotia Pathology Institute (Present address: Pathology Institute, 5788 University Avenue, Halifax, Nova Scotia, Canada)

R. G. CLARK, M.B., F.R.C.S., Professor of Surgery, Sheffield University
}

The ideal jejunostomy feed should provide an adequate intake of energy, nitrogen, electrolytes, water, vitamins, and essential amino-acids, in a moderate volume of fluid, and should contain the correct proportion of calories derived from carbohydrate, fat, and protein. It should be absorbable without gastric digestion and should not cause diarrhoea. Few previously described formulae fulfil these criteria, and some are also expensive and not easily prepared from materials readily available in a ward kitchen. Therefore, we tried to devise a satisfactory formula with none of these drawbacks.

\section{Methods}

The feed consists mostly of milk, with glucose and arachis oil (Prosparol) to provide additional carbohydrate and fat (table I). Each aliquot is homogenized for five minutes in a blender immediately before administration.

The feed was infused intraduodenally through a gastrostomy catheter (Kay, 1964) or a cholecystectomy T-tube at about

TABLE I- fejunostomy Feed. Daily Aliquot $(2,550 \mathrm{ml})$

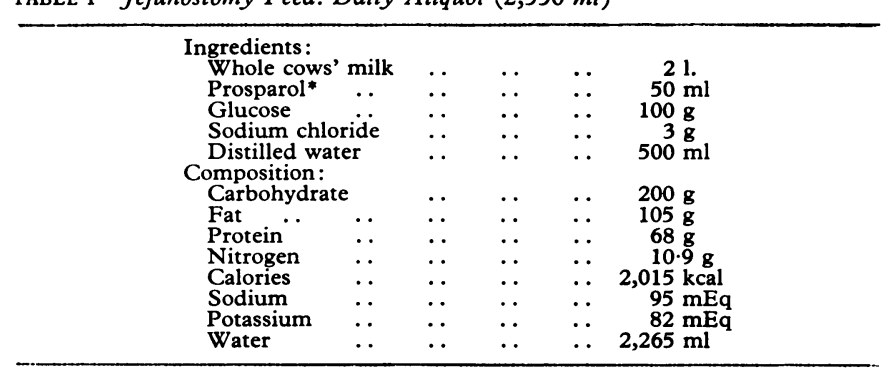

\footnotetext{
*A $50 \%$ emulsion of ground-nut oil in water (B.D.H. Pharmaceuticals Ltd.).
} 
$250 \mathrm{ml} / \mathrm{hr}$ for 10 hours a day. As the feed would not pass through the conventional feeding limb of a gastrostomy catheter the limb was replaced with a modified anaesthesia extension set (BR 33S; Baxter, Norfolk).

Gastric aspirates were inspected (for milky colour) to ensure that the jejunostomy feed was not simply refluxing into the stomach. Balances of sodium, potassium, and nitrogen were constructed from serial determinations (Varley, 1967) of 24-hour collections of urine, faeces, gastric aspirates, and fistula drainage, and daily faecal fat losses (van de Kamer et al., 1949) were recorded. The patients were weighed, always in similar clothing, on an Avery scale.

\section{Patients}

During preliminary evaluation we gave the diet intraduodenally for six days to seven patients (control group) in whom gastrostomy tubes had been inserted to aid postoperative management. Thereafter, it was used for patients with duodenal fistulae whose superficial veins were thrombosed and in whom percaval feeding was thought undesirable. We studied three such patients (fistula group) fed solely via a cholecystectomy $\mathrm{T}$-tube inserted through a jejunostomy.

Control Group.- - Seven men who had undergone vagotomy and pyloroplasty for chronic duodenal ulceration were studied throughout seven 24-hour balance periods (table II) from 8 a.m. one day after operation (day 1). The balance study lasted until day 8 to allow for postoperative intestinal stasis.

TABLE II-Dietary Intake of Control Group

\begin{tabular}{c|c|c}
\hline Day & $\begin{array}{c}\text { Intrajejunal } \\
\text { Infusion (ml) }\end{array}$ & \multicolumn{1}{|c}{ Oral Intake } \\
\hline 1 & 2,550 & $500 \mathrm{ml}$ water \\
2 & 2,550 & $1,000 \mathrm{ml}$ water \\
3 & 2,550 & $1,000 \mathrm{ml}$ water \\
4 & 2,040 & Prepared diet** \\
5 & 1,530 & Prepared diet* \\
6 & 1,015 & Prepared diet* \\
7 & Nil & Prepared diet $(1,500 \mathrm{kcal})$ \\
\hline
\end{tabular}

*To maintain intake of calories, electrolytes, nitrogen, and water.

Fistula Group.-Duodenal fistulae had developed after partial gastrectomy in two males (cases 1 and 2) and total gastrectomy in one female (case 3 ). They received all nutrition intrajejunally for 21,23 , and 14 days respectively.

\section{CASE 1}

A 53-year-old man had undergone partial gastrectomy for a large benign gastric ulcer. Seventeen days later large quantities of gastric and pancreatic juice and bile started leaking through the wound. Nutrition was administered intravenously from day 18 to day 43 , by which time all readily accessible superficial veins were thrombosed. The fistula was not healing, weight loss was pronounced, and severc dehydration had developed accompanied by urea retention and "metabolic" acidosis; therefore a feeding jejunostomy was constructed under local anaesthesia. When the fistula drainage was most profuse (days 46-51), 500-1,000 ml daily was mixed with the feed and returned through the jejunostomy. On day 63 oral feeding was started, and nutrition given via the jejunostomy was decreased gradually until day 69 , when the tube was removed. He was discharged home on day 72 and remained well.

\section{CASES 2 AND 3}

As in case 1, intravenous feeding had to be abandoned. In vicw of our previous experience we started intraduodenal feeding earlier, on day 26 in case 2 and on day 18 in case 3.

\section{Results}

Control Group.-Urine volume became normal soon after the feed was started. Daily sodium and potassium balances became positive on day 1 and were maintained thereafter, but the nitrogen balance was slightly negative until day 5 (fig. 1). Mean daily fat excretion slightly exceeded normal in some patients (table III). Diarrhoea (defined as three or more fluid stools a day) did not develop, but some stools were soft and bulky.
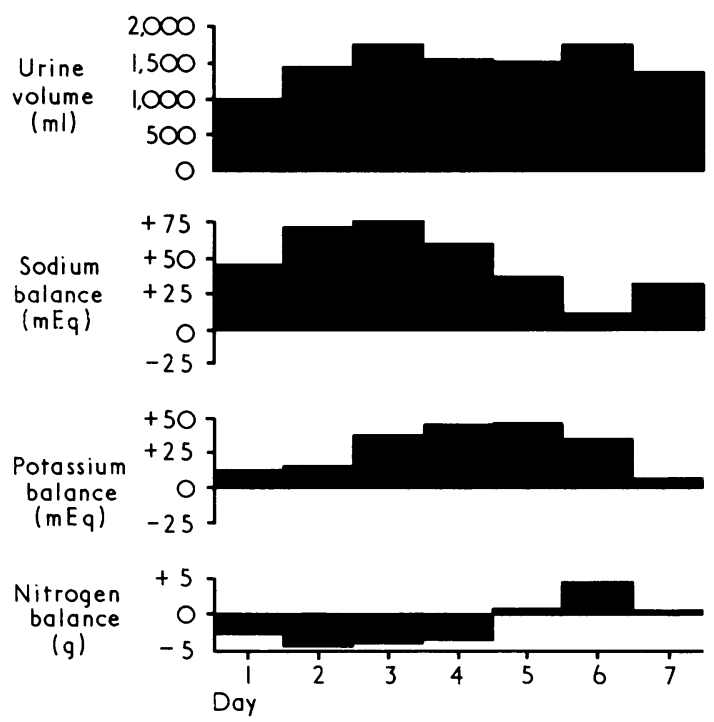

FIG. 1-Control group. Mean daily urine volumes and sodium, potassium, and nitrogen balances during seven-day study period.

TABLE III-Daily Fat Intake and Excretion of Control Group (Subjects A-G)

\begin{tabular}{|c|c|c|c|c|c|c|c|c|}
\hline \multirow{2}{*}{ Day } & \multirow{2}{*}{$\begin{array}{c}\text { Fat } \\
\text { Intake } \\
(\mathbf{g})\end{array}$} & \multicolumn{7}{|c|}{ Daily Faecal Fat Excretion ( $\mathrm{g}$ of Stearic Acid)* } \\
\hline & & A & B & $\mathbf{C}$ & $\mathrm{D}$ & $\mathrm{E}$ & $\mathbf{F}$ & G \\
\hline $\begin{array}{l}1 \\
2 \\
3 \\
4 \\
5 \\
6 \\
7\end{array}$ & $\begin{array}{l}105 \\
105 \\
105 \\
100 \\
100 \\
100 \\
100\end{array}$ & $\begin{array}{l}\bar{z} \\
\frac{2}{2 \cdot 1} \\
-\end{array}$ & $\begin{array}{l}\bar{z} \\
\bar{z} \\
4 \cdot 6 \\
4 \cdot 0\end{array}$ & $\begin{array}{l}= \\
= \\
\overline{10.5} \\
21.8 \\
3.7\end{array}$ & $\begin{array}{c}\bar{Z} \\
\frac{25 \cdot 7}{6 \cdot 3} \\
\frac{6 \cdot 2}{10 \cdot 2}\end{array}$ & $\begin{array}{l}\text { 二 } \\
29 \cdot 2 \\
12 \cdot 2 \\
\frac{8 \cdot 9}{8 \cdot 7}\end{array}$ & $\begin{array}{c}\overline{7} \\
6 \overline{9 \cdot 4} \\
\overline{14 \cdot 6} \\
=\end{array}$ & $\begin{array}{r}= \\
\overline{2} \\
28 \cdot 3 \\
30 \cdot 8 \\
4 \cdot 1 \\
3 \cdot 0\end{array}$ \\
\hline $\begin{array}{l}\text { Mea } \\
\text { creti }\end{array}$ & $\begin{array}{l}x- \\
\text { to } 7\end{array}$ & 0.3 & $1 \cdot 2$ & $5 \cdot 1$ & $6 \cdot 0$ & 8.4 & $12 \cdot 0$ & 9.5 \\
\hline
\end{tabular}

*Norrnal mean daily output over five or more days $\leqslant 6 \mathrm{~g}$ stcaric acid.

Fistula Group.-In case 1 (fig. 2A) urine volume increased as fistula drainage decreased. Despite the copious drainage the nitrogen and potassium balances were positive throughout, except for potassium balance on day 55 . The sodium balance fluctuated: it was mainly negative when the fistula was draining freely and then became more stable. This patient excreted increased amounts of fat, but his stools were not watery and their nitrogen content was small. His weight increased by $6 \mathrm{~kg}$ while he was on the feed. The findings in case 2 (fig. 2B) and case 3 (fig. 2C) were similar.

\section{Discussion}

One of the first descriptions of intrajejunal feeding was by Jones (1916), who, by using a feed of milk and raw eggs, achieved a daily intake of $2,100 \mathrm{kcal}$ and $120 \mathrm{~g}$ of protein in a total volume of $2,500 \mathrm{ml}$. This feed would be ideal but for its tendency to block the feeding tube (the author recommended straining through four layers of fine linen). Most if not all other jejunostomy feeds cause some degree of diarrhoea, which was severe 

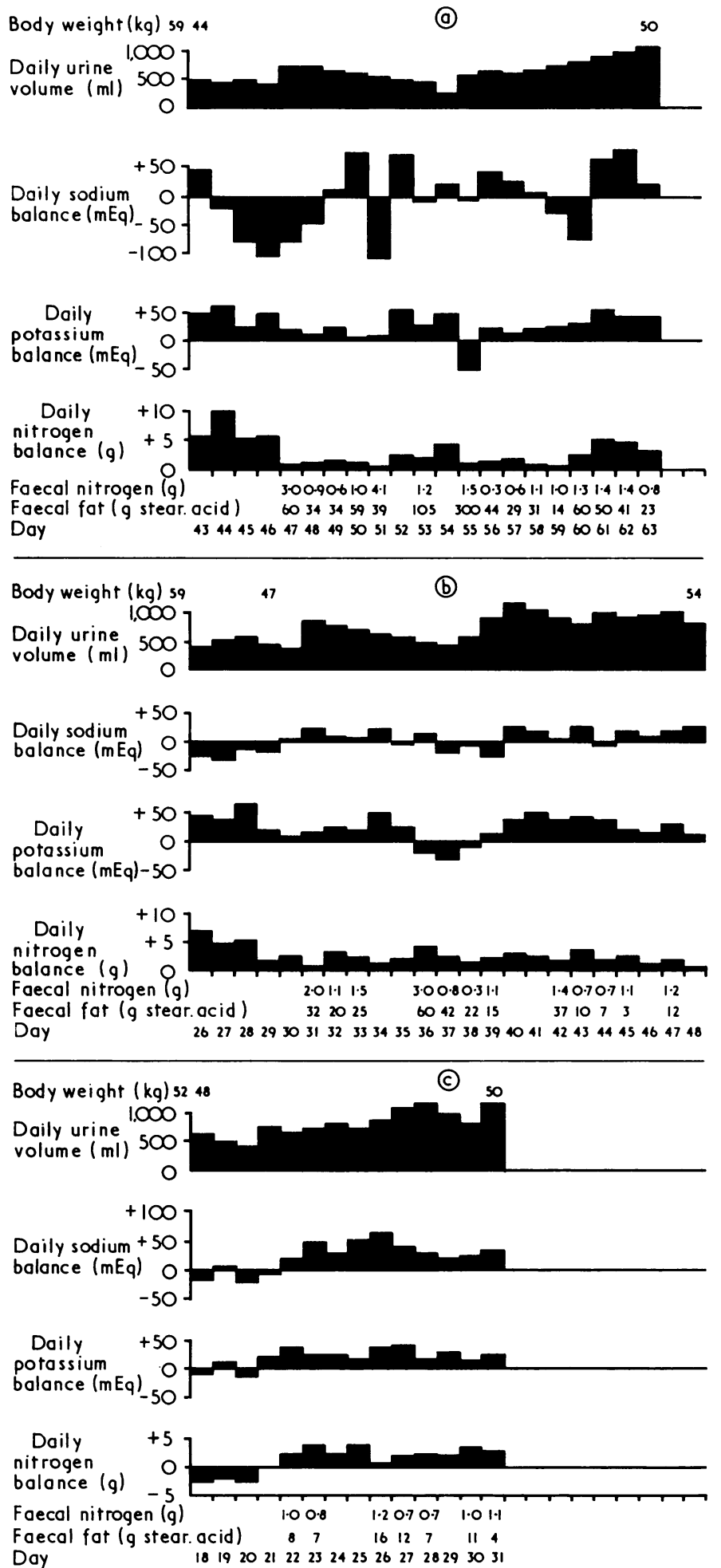

Day $\quad 1819202122232425262728293031$

FIG. 2-Fistula group: A. Case 1 (partial gastrectomy), patient weighed $59 \mathrm{~kg}$ preoperatively; B. Case 2 (partial gastrectomy), patient weighed $59 \mathrm{~kg}$ preoperatively; Case 3 (total gastrectomy), patient weighed $52 \mathrm{~kg}$ preoperatively.

in five of six patients (table IV) whom we fed with diets recommended by Masterton et al. (1963). Others (Ravdin et al., 1940; Wilkinson et al., 1950) have a calorie : nitrogen ratio much less than recommended (Calloway and Spector, 1954) for optimal nitrogen utilization, and some contain components that are expensive-for example, casein hydrolysate (Co Tui et al., 1944) -or not widely available (Case et al., 1949; Boles and Zollinger, 1952; Pareira and Heeb, 1958; Moore and Ball, 1952).

The criteria for a jejunostomy feed are as follows.

Sodium.-Most patients who require intrajejunal feeding have
TABLE IV-Diarrhoeal Effect of Two Other Feeds*

\begin{tabular}{|c|c|c|c|c|}
\hline \multirow{2}{*}{$\begin{array}{c}\text { No. of } \\
\text { Patients }\end{array}$} & \multirow[b]{2}{*}{ Diagnosis } & \multicolumn{2}{|r|}{ Feed } & \multirow{2}{*}{ Diarrhoea } \\
\hline & & kcal & Route & \\
\hline$\frac{1}{4 \dagger}$ & $\begin{array}{l}\text { Dysphagia; “"corkscrew } \\
\text { oesophagus" } \\
\text { Dysphagia; pseudobulbar palsy } \\
\text { After vagotomy and pyloro- } \\
\text { plasty for chronic duodenal } \\
\text { ulceration } \quad .\end{array}$ & $\begin{array}{r}3,000 \\
3,000 \\
2,000\end{array}$ & $\begin{array}{l}\text { Gastrostomy } \\
\text { Gastrostomy } \\
\text { Intraduodenal }\end{array}$ & $\begin{array}{l}\text { Severe } \\
\text { Severe } \\
\text { Severe in } 3\end{array}$ \\
\hline
\end{tabular}

tComparable to our control group patients.

large extrarenal sodium losses. The sodium content of our feed is readily varied between 50 and $100 \mathrm{mEq}$, and when the sodium loss exceeds $100 \mathrm{mEq}$ daily isotonic saline or some of the fistula drainage can be added.

Potassium is necessary to replace losses via the fistula. Our feed provides $82 \mathrm{mEq} \mathrm{K}$ daily and can be supplemented by adding some of the drainage.

Water.-The water content should be sufficient to replace losses via the faeces, skin, and lungs, and to maintain the urine volume to clear the urea load, but small enough to avoid water retention, particularly in the early postoperative period. 2,500 to $3,000 \mathrm{ml}$ is an adequate daily intake for an adult with normal fluid losses (Le Quesne, 1955). The water content of our feed $(2,265 \mathrm{ml})$ was increased, up to $3,265 \mathrm{ml}$ daily, when losses were excessive.

Calories.-The energy expenditure of sedentary inpatients before and after surgery of medium severity and without major changes in body temperature is said to approximate $2,000 \mathrm{kcal}$ a day (Kinney, 1960; Levey et al., 1960). Our diet provides 2,015 kcal a day.

Nitrogen.-The recommended daily protein intake of an active healthy man in $0.85 \mathrm{~g} / \mathrm{kg}$ of body weight (Davidson and Passmore, 1969). As body protein is depleted in most patients who require intrajejunal feeding, we included $68 \mathrm{~g}$ of protein daily, all of high biological value.

Vitamins and Essential Amino-acids.-The recommended intake (Food and Nutrition Board, 1968; Rose, 1957) of these components and their amounts in a daily aliquot of our diet are shown in table V. Our feed provides sufficient essential aminoacids but requires vitamin supplementation.

TABLE v-Daily Intake of Vitamins and Essential Amino-acids

\begin{tabular}{|c|c|c|c|c|c|c|}
\hline \multicolumn{2}{|c|}{ Vitamin } & \multirow{2}{*}{$\begin{array}{c}\begin{array}{c}\text { Recom- } \\
\text { mended } \\
\text { for Adult } \\
\text { Males* }\end{array} \\
5,000\end{array}$} & \multirow{2}{*}{$\begin{array}{c}\begin{array}{c}\text { Jejun- } \\
\text { ostomy } \\
\text { Feed } \\
(2,250 \mathrm{ml})\end{array} \\
2,600- \\
20,000\end{array}$} & \multirow{2}{*}{$\begin{array}{l}\text { Amino-acid } \\
\text { Isoleucine }\end{array}$} & \multirow{2}{*}{$\begin{array}{c}\begin{array}{c}\text { Recom- } \\
\text { mended } \\
\text { for } \\
\text { Adultst } \\
(\mathrm{g})\end{array} \\
0.7\end{array}$} & \multirow{2}{*}{$\begin{array}{c}\begin{array}{c}\text { Jejun- } \\
\text { ostomy } \\
\text { Feed } \\
(2,250 \mathrm{ml}) \\
(\mathrm{g})\end{array} \\
5 \cdot 0\end{array}$} \\
\hline $\mathbf{A}$ & (IU) & & & & & \\
\hline $\begin{array}{l}\mathbf{B}^{1} \\
\mathbf{B}^{2} \\
\mathbf{B}^{6} \\
\mathbf{B}^{12} \\
\text { Folic acid } \\
\text { Niacin } \\
\text { C } \\
\text { D }\end{array}$ & $\begin{array}{l}(\mathrm{mg}) \\
(\mathrm{mg}) \\
(\mathrm{mg}) \\
(\mu \mathrm{g}) \\
(\mu \mathrm{g}) \\
(\mathrm{mg}) \\
(\mathrm{mg}) \\
(\mathrm{IU})\end{array}$ & $\begin{array}{c}1 \cdot 3 \\
1 \cdot 7 \\
2.0 \\
5.0 \\
400 \\
17 \cdot 0 \\
60.0 \\
400\end{array}$ & $\begin{array}{c}20,8 \\
0 \cdot 8 \\
3 \cdot 2 \\
1 \cdot 0 \\
13 \cdot 2 \\
2 \cdot 6 \\
1 \cdot 8 \\
36 \cdot 0 \\
10-80\end{array}$ & $\begin{array}{l}\text { Leucine } \\
\text { Lysine } \\
\text { Methionine } \\
\text { Phenylalanine } \\
\text { Threonine } \\
\text { Tryptophan } \\
\text { Valine }\end{array}$ & $\begin{array}{l}1 \cdot 1 \\
0.8 \\
1.1 \\
1.1 \\
0.5 \\
0 \cdot 25 \\
0.8\end{array}$ & $\begin{array}{l}7 \cdot 2 \\
5.4 \\
1.5 \\
3.7 \\
3.5 \\
1.2 \\
5.2\end{array}$ \\
\hline
\end{tabular}

-Food and Nutrition Board, 1968.

tRose, 1957.

Composition.-Many artificial diets, particularly those given intravenously, reach high calorie levels only by increasing fat intake to unphysiological levels. In our feed calorie sources ( $40 \%$ from carbohydrate, $47 \%$ from fat, and $13 \%$ from protein) are close to normal (Keele and Neil, 1961). The calorie : nitrogen ratio (185 kcal per $1 \mathrm{~g}$ nitrogen) ensures that administered protein is used for tissue anabolism (Calloway and Spector, 1954) rather than as an energy supply.

RESPONSE TO FEED

Because their response to any dietary regimen is influenced by 
their metabolic response to the trauma, patients who have only just undergone surgery (our control group) may not be considered as representative of patients who require jejunostomy feeding. However, since many of the latter have undergone surgery recently, and the metabolic response to surgery is often prolonged by postoperative complications (Moore and Ball, 1952) the two situations are probably not so different.

In our control group positive sodium balance was maintained -no doubt aided by postoperative sodium retention-and positive potassium balance and normal urine volumes were achieved despite the tendency to $K$ loss and water retention due to the metabolic response to surgery. However, the characteristic postoperative negative nitrogen balance, though substantially reduced, was not reversed by the feed. (These results have been published in detail elsewhere-Hindmarsh and Clark, 1973.) Intestinal stasis may have contributed to the reduced fat excretion by promoting storage of faeces in the colon; however, most patients had normal bowel action by day 4 or 5 , so any significant degree of fat malabsorption should have been detected.

We are not, of course, recommending that all patients who have undergone vagotomy and pyloroplasty should be fed by jejunostomy: most of them recover equally well without such measures.

The patients in our fistula group achieved adequate urine volumes and satisfactory sodium, potassium, and nitrogen balances. Two had fairly severe steatorrhoea, probably due to loss of pancreatic lipase and bile salts in the fistula drainage, but much of the administered fat ( $105 \mathrm{~g}$ daily) was absorbed; had medium-chain triglyceride been substituted absorption might have been greater. Though most of the feed's total nitrogen was whole protein it appeared to be hydrolysed and absorbed. Normal amounts of nitrogen were excreted in the faeces despite sizable losses of gastric and pancreatic juices by all the patients, so it is unlikely that any had gross protein malabsorption. However, mild protein malabsorption cannot be excluded. Protein not absorbed by the small intestine may have been digested by proteolytic bacteria in the large intestine, and the resultant nitrogen derivatives absorbed, resulting in normal faecal nitrogen excretion.

Masterton et al. (1963) stated that jejunostomy feeds should have an osmolarity similar to that of body fluids (about 300 $\mathrm{mOsm} / 1$.), but no patient receiving our feed (about $550 \mathrm{mOsm} / 1$.) had diarrhoea. We used glucose as the added carbohydrate, since the severe diarrhoea that developed in those to whom we gave Masterton's diets (table IV) could have been due to intolerance of the large lactose content (Peaston, 1967).

We thank Miss Norma Lauder, departmental dietician, for her valuable help; the Misses A. Brent and J. Wright, ward sisters, for their enthusiastic co-operation; and Miss Ursula Matthews and her staff in the Editorial Service to the Faculty of Medicine, Dalhousie University, for help with the manuscript. We are indebted to the Endowment Fund of the United Sheffield Hospitals for financial support and to B.D.H. Pharmaceuticals Ltd. for supplies of Prosparol.

Requests for reprints should be addressed to: Dr. J. T. Hindmarsh, The Royal Infirmary, Sheffield.

\section{References}

Boles, T., jun., and Zollinger, R. M. (1952). Archives of Surgery, 65, 358 Calloway, D. H., and Spector, H. (1954). American fournal of Clinical Nutrition, 2405.

Case, C. T., Zollinger, R. M., McMullen, C. H., and Brown, J. B. (1949) Surgery, 26, 364

Co Tui, et al. (1944). Annals of Surgery, 120, 99.

Davidson, S., and Passmore, R. (1969). In Human Nutrition and Dietetics, 4th edn., p. 85. Edinburgh, Livingstone.

Food and Nutrition Board, National Academy of Sciences-National Research Council (U.S.A.) (1968). Recommended Dietary Allowances, 7th rev. edn., p. 102, Publ. No. 1694. National Academy of Sciences Washington, D.C.

Hindmarsh, J. T., and Clark, R. G. (1973). British fournal of Surgery. $60,589$.

Jones, C. R. (1916). Surgery, Gynecology and Obstetrics, 22, 236.

Jones, C., and McIntosh, N. (1973). Lancet, 1, 156.

Kay, A. W. (1964). British Medical fournal, 1, 822

Keele, C. A., and Neil, E. (1961). In Samson Wright's Applied Physiology, 10th edn., p. 442. London, Oxford University Press.

Kinney, J. M. (1960). Bulletin of the Nerv York Academy of Medicine, 36, 617 .

Le Quesne, L. P. (1955). In Fluid Balance in Surgical Practice, p. 11 Chicago, Year Book Publishers.

Levey, S., Czarnecki, N., Krieger, H., and Abbott, W. E. (1960). Federation Proceedings, 19, 325.

Masterton, J. P., Dudley, H. A. F., and MacRae, S. (1963). British Medical

Fournal, 2, 909 .
Moore, F. D., and Ball, M. R. (1952). Metabolic Response to Surgery, p. 80, 145. Springfield, Illinois, Thomas.

Pareira, M. D., and Heeb, M. A. (1958). Archives of Surgery, 77, 851.

Peaston, M. J. T. (1967). Postgraduate Medical fournal, 43, 317.

Ravdin, I. S., Stengel, A., jun., and Prushankin, M. (1940). Fournal of the American Medical Association, 114, 107.

Rose, W. C. (1957). Nutrition Abstracts and Reviews, 27, 631.

van de Kamer, J. H., Huinink, H. B., and Weyers, H. A. (1949). Fournal of Biological Chemistry, 177, 347.

Varley, H. (1967). In Practical Clinical Biochemistry, 4th edn., p. 194, 491. London Heinemann.

Wilkinson, A. W., Billing, B. H., Nagy, G., and Stewart, C. P. (1950). Lancet, 1,533 .

Wilmore, D. W., and Dudrick, S. J. (1969). Archives of Surgery, 98, 256.

\title{
Measles and Other Virus-specific Immunoglobulins in Multiple Sclerosis
}

\author{
MARGARET HAIRE, K. B. FRASER, J. H. D. MILLAR
}

British Medical fournal, 1973, 3, 612-615

\section{Summary}

Immunoglobulins $M$ and $G$ specific for measles, herpes simplex, and rubella viruses were assayed by the fluorescent antibody method in sera and cerebrospinal fluids

\footnotetext{
Department of Microbiology, The Queen's University of Belfast, Belfast BT12 6BN

MARGARET HAIRE, M.D., M.R.C.PATH., Senior Research Fellow

K. B. FRASER, M.D., D.SC., Professor of Microbiology

Department of Neurology, Royal Victoria Hospital, Belfast BT12 6BN

J. H. D. MILLAR, M.D., F.R.C.P., Consultant Neurologist
}

(C.S.F.) obtained simultaneously from 30 patients with multiple sclerosis, 30 patients with other neurological diseases, and 30 "normal" control subjects. Sera of 11 out of 30 patients with multiple sclerosis had IgM which reacted specifically with measles virus-infected cells, compared with 2 out of 30 of the patients with other neurological diseases and none of the 30 normal controls. Virus-specific IgM was not found in C.S.F. by this method.

The geometric mean titre of measles virus-specific IgG in serum was significantly higher in the multiple sclerosis group than in either control group, and while IgG specific for all three viruses was found in C.S.F., suggesting transfer across the blood-brain barrier, measles IgG predominated. 